\section{Category}

Metal-Catalyzed Asymmetric Synthesis and Stereoselective Reactions

\section{Key words}

asymmetric [3+2] cycloaddition

epoxides

furans

nickel
W. CHEN, X. FU, L. LIN, X. YUAN, W. LUO, J. FENG, X. LIU, X. FENG* (SICHUAN UNIVERSITY, CHENGDU, P. R. OF CHINA)

An Asymmetric [3+2] Cycloaddition of Alkynes with Oxiranes by Selective C-C Bond Cleavage of Epoxides:

Highly Efficient Synthesis of Chiral Furan Derivatives

Chem. Commun. 2014, 50, 11480-11483.

\title{
Chiral Furans via Asymmetric [3+2] Cycloaddition
}

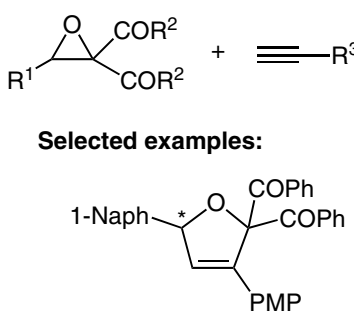

$95 \%$ yield, $91 \%$ ee $(24 \mathrm{~h})$

$\mathrm{PMP}=4-\mathrm{MeOC}_{6} \mathrm{H}_{4}$<smiles>O=C(Nc1ccccc1)C1(C(=O)Oc2ccccc2)C=CC(C=Cc2ccccc2)O1</smiles>

$97 \%$ yield, $90 \%$ ee $(24 \mathrm{~h})$
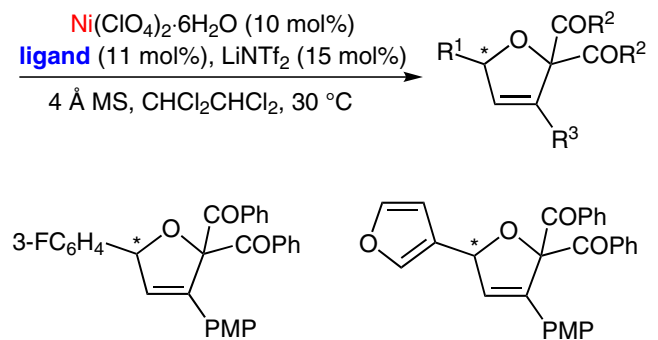

$57 \%$ yield, $92 \%$ ee $(96 \mathrm{~h})$

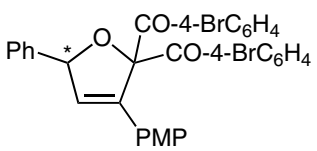

$98 \%$ yield, $90 \%$ ee $(24 \mathrm{~h})$<smiles>O=C(c1ccccc1)C1(c2ccccc2)OC(c2ccoc2)C=C1[PH2+]</smiles>

$81 \%$ yield, $95 \%$ ee (24 h)

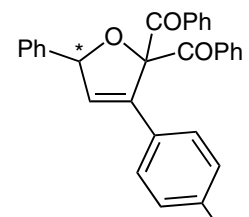

$93 \%$ yield, $91 \%$ ee OEt (24 h)
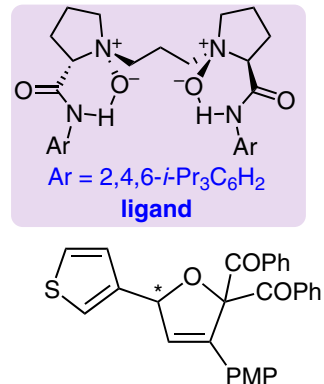

$90 \%$ yield, $95 \%$ ee (24 h)

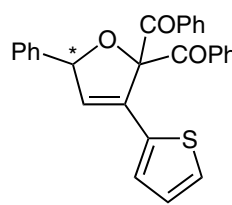

$90 \%$ yield, $92 \%$ ee (92 h)

Asymmetric [3+2] cycloaddition with an alkene substrate:

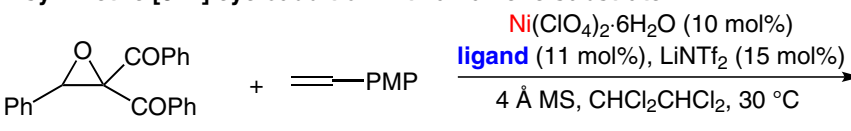

Proposed activation model:

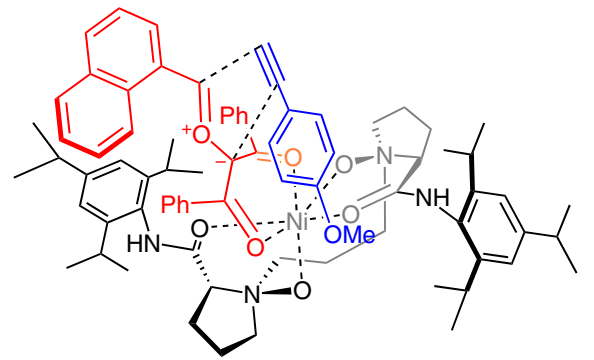

Significance: Tetrahydrofurans and 2,5-dihydrofurans containing a stereocenter are often found in natural products and medicinal compounds. $\mathrm{Ni}\left(\mathrm{ClO}_{4}\right)_{2} \cdot 6 \mathrm{H}_{2} \mathrm{O}$ in the presence of an $N, N^{\prime}$-dioxide ligand promotes the asymmetric [3+2] cycloaddition of alkynes with epoxides via a regioselective $\mathrm{C}-\mathrm{C}$ bond cleavage to give 2,5-dihydrofurans. A catalytic amount of $\mathrm{LiNTf}_{2}$ was necessary to increase the yield of the cycloaddition process.

SYNFACTS Contributors: Hisashi Yamamoto, Sukalyan Bhadra Synfacts 2015, 11(1), 0054 Published online: 15.12.2014 Dol: 10.1055/s-0034-1379747; Reg-No.: H15314SF
Comment: Notably, the asymmetric [3+2] cycloaddition of an alkene and an epoxide under optimized conditions afforded an optically active tetrahydrofuran derivative. According to the proposed activation model, the chiral nickel complex activates the epoxide to form a carbonyl ylide intermediate, through which the alkyne attacks from the re face, leading to the $R$-configured product. 